\title{
Monitoring of Antibodies Titre Against Canine Distemper Virus in Ferrets Vaccinated with a Live Modified Vaccine
}

\author{
L. PAVLAČÍIK ${ }^{1}$, V. CELER Jr. ${ }^{2}$, V. KAJEROVÁ ${ }^{1}$, V. JEKL ${ }^{3}$, \\ Z. KNOTEK ${ }^{3}$, I. LITERÁK ${ }^{1}$
}

\begin{abstract}
${ }^{1}$ Department of Biology and Wildlife Diseases, Faculty of Veterinary Hygiene and Ecology, University of Veterinary and Pharmaceutical Sciences Brno, Czech Republic

${ }^{2}$ Department of Microbiology and Immunology, Faculty of Veterinary Medicine, University of Veterinary and Pharmaceutical Sciences Brno, Czech Republic

${ }^{3}$ Avian and Exotic Animal Clinic, Faculty of Veterinary Medicine, University of Veterinary and Pharmaceutical Sciences Brno, Czech Republic
\end{abstract}

Received January 17, 2006

Accepted August 27, 2007

\begin{abstract}
Pavlačík L., V. Celer Jr., V. Kajerová, V. Jekl, Z. Knotek, I. Literák: Monitoring of Antibodies Titre Against Canine Distemper Virus in Ferrets Vaccinated with a Live Modified Vaccine. Acta Vet. Brno 2007, 76: 423-429.

A group of five ferrets vaccinated against the canine distemper virus (CDV) was evaluated as to the onset of anti-CDV antibody production and the serum levels of the animals were monitored for one year.

The ferrets were immunized with a live attenuated vaccine. The vaccination pattern was as follows: primary vaccination at the age of 6 weeks, first revaccination at 30 days after primary vaccination, and second revaccination after another 30 days. Blood samples were taken prior to primary vaccination and then at 30 -day intervals (sampling 1 to 12 ). The whole experimental cycle covered the period of one year from primary vaccination (till the age of 1 year and 6 weeks). Serum samples were analysed for anti-CDV virus-neutralisation antibodies using a virusneutralisation test using the Onderstepoort CDV strain. All ferrets had zero virus-neutralisation antibody titres before primary vaccination. Two ferrets produced virus-neutralisation antibodies as a response to first revaccination. A stable antibody level (titre 256) was maintained between months 4 and 11 after primary vaccination and a sudden increase in antibody titre (titres 512 and 1024 - 2048) occurred in both animals in months 11 and 12. The reason for the abrupt rise in antibody titres in the two animals remains unclear. No anti-CDV seroconversion was observed in the three remaining animals. Regarding the results obtained in this study we do not consider commonly recommended vaccination with a live attenuated anti-CDV vaccine as an effective method of antibodies induction against distemper in young ferrets.
\end{abstract}

Small mammals, Mustelidae, immunoprophylaxis, Morbillivirus

Caused by the RNA virus from the Paramyxoviridae family (Kelleher 2001; Rosenthal 2004), canine distemper is one of the most serious diseases found in ferrets. No specific therapy is available to treat this infection and the mortality is around $100 \%$ (McDonald and Lariviere 2001; Antinoff 2004).

Approaches to vaccination of ferrets against canine distemper caused by the CDV differ worldwide. A monovalent vaccine for ferrets called Fervac D (Fervac-D, United Vaccines, Madison, WI) has been available in the US for several years (Fox 1998; Schoemaker 2002; Quesenberry and Orcutt 2004), polyvalent dog vaccines based on modified live virus are still used in Europe (Lewington 2003), e.g. a vaccine from the Nobivac and Decalvac DHPPiL line (Intervet, NE) is used in Great Britain and some other European countries. The canine distemper strain contained in these vaccines is derived from the Onderstepoort strain cultivated on VERO cell lines. Vaccine Galaxy-D (Solvay Animal Health) can be employed, too, but it is not originally intended for ferrets and its efficacy against canine

Address for correspondence:

MVDr. Lukáš Pavlačík, Ph.D.

Štefánikova 1029

54401 Dvůr Králové nad Labem

Czech Republic 
distemper in ferrets has not been confirmed with confidence yet (Langlois 2005). Only polyvalent vaccines have been available in Australia and New Zealand so far and there is certain consensus between veterinary practitioners and companies that polyvalent vaccines for dogs may be used in ferrets there, too (Lewington 2003). The basic prerequisite is that the vaccines are prepared using tissue cultures other than from ferrets, i.e. for example monkey tissue cultures or cultures from chicken embryos. Inactivated canine distemper virus vaccines cannot be recommended due to reported unreliable efficacy (Newcomer 1998). Svoboda (1998) recommends vaccination with modified live virus passaged in chicken cells. Fox (1998) presents the possibility of using a modified live vaccine prepared on tissue cultures from chicken embryos (CETCO). The author does not regard inactivated vaccines as reliable and does not recommend their use in ferrets. He also reports very good results achieved in ferrets with vaccines intended for dogs (e.g. Nobivac D, Nobivac DH2, Trimune) or Vanguard DA2PL (Pfizer Animal Health, Belgium). One relatively often discussed issue is the potential agreement between the canine distemper strain used for vaccine preparation and the presence of a corresponding field strain in the given region (Fox 1998; Lewington 2003).

The first vaccination in ferrets is carried out at 6 to 8 weeks of age. The reported half-life of the maternal antibodies is 9.4 days (Appel and Harris 1988). Vaccination before week 6 is not advisable due to possible interactions of vaccine antigens with maternal antibodies (Langlois 2005). The next vaccination is administered at week 10 to 12 and then at week 13 to 14 of age. Young ferrets should be kept in isolation for another two weeks after vaccination. The animals are then kept immune by annual revaccination. Vaccination of ferrets against CDV in the Czech Republic is performed with polyvalent vaccines for dogs based on live CDV modified on VERO cells, suited to both ferrets and dogs as far as safety is concerned. Post-vaccination antibody control, however, has not been paid due attention as yet.

The goal of this study was to assess the onset of antibody production and monitor antibody blood levels at regular intervals in a group of ferrets vaccinated with a vaccine of a type commonly used against CDV in both dogs and ferrets in the Czech Republic.

\section{Materials and Methods}

Animals used in the experimental study

The study used 5 domestic ferrets (Mustela putorius furo) from 6 weeks of age. The animals were three females and two males, not related to one another. The ferrets were kept in two separate groups - males and females - in cages with five solid walls. All animals were kept in a single room at the same hygienic conditions. The animals were implanted microchips in the dorsal region between the shoulder blades. They were referred to by codes $\mathrm{F}$ plus numbers 1 to 5 in the log. Ferrets F2, F4 and F5 were females and ferrets F1 and F3 were males. The ferrets were fed commercial granulated food ad libitum and had permanent access to drinking water.

Vaccination

The ferrets were immunized against CDV with commonly used commercial vaccines Biocan ${ }^{\circledR}$ Puppy - D + Biocan ${ }^{\circledR}$ Puppy - P and Biocan ${ }^{\circledR}$ DHP + Biocan $^{\circledR}$ L (Bioveta, a.s., Ivanovice na Hané, Czech Republic). Biocan ${ }^{\circledR}$ Puppy - D is a live attenuated anti-CDV vaccine; Biocan ${ }^{\circledR}$ Puppy - P contains attenuated, lyophilised canine parvovirus and Biocan ${ }^{\circledR}$ DHP contains inactivated CDV, infectious hepatitis and infectious laryngotracheitis virus. Biocan ${ }^{\circledR} \mathrm{L}$ is an inactivated vaccine against leptospirosis containing Leptospira canicola and L. grippotyphosa. The vaccination pattern was as follows: primary vaccination at 6 weeks of age with vaccine Biocan ${ }^{\circledR}$ Puppy - D + Biocan ${ }^{\circledR}$ Puppy - P, first revaccination at 30 days after primary vaccination with vaccine Biocan ${ }^{\circledR} \mathrm{DH}+\mathrm{Biocan}{ }^{\circledR} \mathrm{L}$, and second revaccination with vaccine Biocan ${ }^{\circledR} \mathrm{DH}+$ Biocan $^{\circledR} \mathrm{L}$ after another 30 days. The ferrets received triple anti-CDV immunization. The vaccines were given subcutaneously in the region between the shoulder blades.

Blood sampling

The ferrets were weighed prior to individual blood sampling and a basic clinical examination was performed, including behaviour and posture assessment, temperature, pulse and respiratory rate, check of vestiture, check of mucosal membrane colour, palpation and examination for the size of submandibular and popliteal lymph nodes, cardiovascular and respiratory system auscultation and abdominal palpation.

To limit stress and prevent potential undesirable movement of the animals during fixation and blood collection, 
a short-time inhalation anaesthesia with a mixture of isofluran (Rhodia, Torrexpharma, GmbH, Vienna, Austria) and oxygen was performed using the anaesthesiology mask, the initial concentration being 5\%. After assuming a lateral position, the ferrets were transferred onto a heated pad kept at a constant temperature of $39^{\circ} \mathrm{C}$. Isofluran concentration was decreased to $3 \%$ at this point. Skin in the manubrium sterni region was disinfected with chlorhexidine. Blood was sampled from v. cava cranialis. The amount of blood taken ranged between 0.8 and $1.5 \mathrm{ml}$ (depending on the body mass). After the blood was taken, the ferrets were administered physiological saline with $5 \%$ glucose saline $(5 \mathrm{ml} / \mathrm{kg}$ of live weight sc.). The influx of anaesthesiology gas was discontinued and the patient inhaled oxygen only till the recovery. The lateral reflex was resumed within 1 min as a maximum in all cases.

Blood was collected before primary vaccination (sample 0 ) and then at regular 30-day intervals (samples 1 to 12). The whole examination cycle covered the period of one year from primary vaccination at 6 weeks of age (till the age of 1 year and 6 weeks).

The blood samples were centrifuged $(g=32)$ for $10 \mathrm{~min}$. The serum was frozen and kept at $-20{ }^{\circ} \mathrm{C}$ pending analysis (approximately 2 - 3 weeks).

Detection of virus-neutralisation antibodies

The serum samples were analyzed for anti-CDV virus-neutralisation antibodies using a virus-neutralisation test after inactivation at $60{ }^{\circ} \mathrm{C}$ for $30 \mathrm{~min}$. The serum samples were serially diluted in Dulbecco's minimal essential medium (DMEM) with twofold dilution, the initial dilution ratio being $1: 2$. The analysis was based on the Onderstepoort CDV strain (Haig 1948) obtained from Prof. Dr. M. Vandevelde,University of Bern. The viral culture was diluted in DMEM to $100 \mathrm{TCID}_{50}$ in $50 \mu 1$. The virus was mixed with the diluted serum samples in a microtitration plate and incubated at $37^{\circ} \mathrm{C}$ for 1 hour. Then $100 \mu 1$ of Vero cell suspension was added to each well. The plates were incubated at $37^{\circ} \mathrm{C}$ for 3 - 4 days in a $5 \% \mathrm{CO}_{2}$-enriched atmosphere. Each serum dilution was analysed in 3 wells. Antibody titre was determined as serum dilution in which the cytopathic effect was prevented in at least two wells.

\section{Results}

No symptoms of disease were observed in the ferrets throughout the experiment. Rectal temperature did not exceed the physiological range of $37.8-40.0{ }^{\circ} \mathrm{C}$ (Brown 1996). All the ferrets had no virus-neutralisation antibody titres prior to primary vaccination. No antiCDV seroconversion was observed in three animals (F2, F4 and F5). Both males (F1 and F2) responded to first revaccination by producing virus-neutralisation antibodies. A stable antibody level (titre 256) was maintained between month 4 and 11 after primary vaccination and a sudden increase in antibody titre (titres 512 and 1024 - 2048) occurred in both animals

Table 1. Antibody titres after vaccination with a live anti-CDV vaccine.

\begin{tabular}{|c|c|c|c|c|c|c|}
\hline & \multicolumn{5}{|c|}{ ferrets } & \multirow{2}{*}{$\begin{array}{c}\text { blood } \\
\text { sample No. } \\
\text { (Months) }\end{array}$} \\
\hline & F1 & F2 & F3 & F4 & F5 & \\
\hline \multirow{13}{*}{ 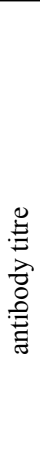 } & 0 & 0 & 0 & 0 & 0 & $0^{\mathrm{a}}$ \\
\hline & 0 & 0 & 0 & 0 & 0 & $1^{\mathrm{b}}$ \\
\hline & 32 & 0 & 64 & 0 & 0 & $2^{c}$ \\
\hline & 64 & 0 & 64 & 0 & 0 & 3 \\
\hline & 256 & 0 & 128 & 0 & 0 & 4 \\
\hline & 256 & 0 & 256 & 0 & 0 & 5 \\
\hline & 256 & 0 & 256 & 0 & 0 & 6 \\
\hline & 256 & 0 & 256 & 0 & 0 & 7 \\
\hline & 256 & 0 & 256 & 0 & 0 & 8 \\
\hline & 256 & 0 & 256 & 0 & 0 & 9 \\
\hline & 256 & 0 & 256 & 0 & 0 & 10 \\
\hline & 512 & 0 & 1024 & 0 & 0 & 11 \\
\hline & 512 & 0 & 2048 & 0 & 0 & 12 \\
\hline
\end{tabular}

${ }^{\mathrm{a}}$ - first vaccination, ${ }^{\mathrm{b}}-$ second vaccination, ${ }^{\mathrm{c}}-$ third vaccination in months 11 and 12. The development of anti-CDV virus-neutralisation antibody titres after vaccination with Biocan $^{\circledR}$ is shown in Table 1 and Figs 1 and 2.

\section{Discussion}

Laboratory evidence of CDV in ferrets can be based on different variants of the imunofluorescence testing, RT-PCR and/ or nested-PCR (Langlois 2005). The evaluation of vaccination efficacy in our study was based on a virus-neutralisation test. The virus-neutralisation test has still been regarded as a standard serological test providing a good correlate of protection against viral infection (Kennedy 2005). All serum samples were analysed at least three times, with always the same result.

Opinions on optimum protection of ferrets against CDV differ (Quesenberry 1997; Newcomer 1998; Fox 1998; 


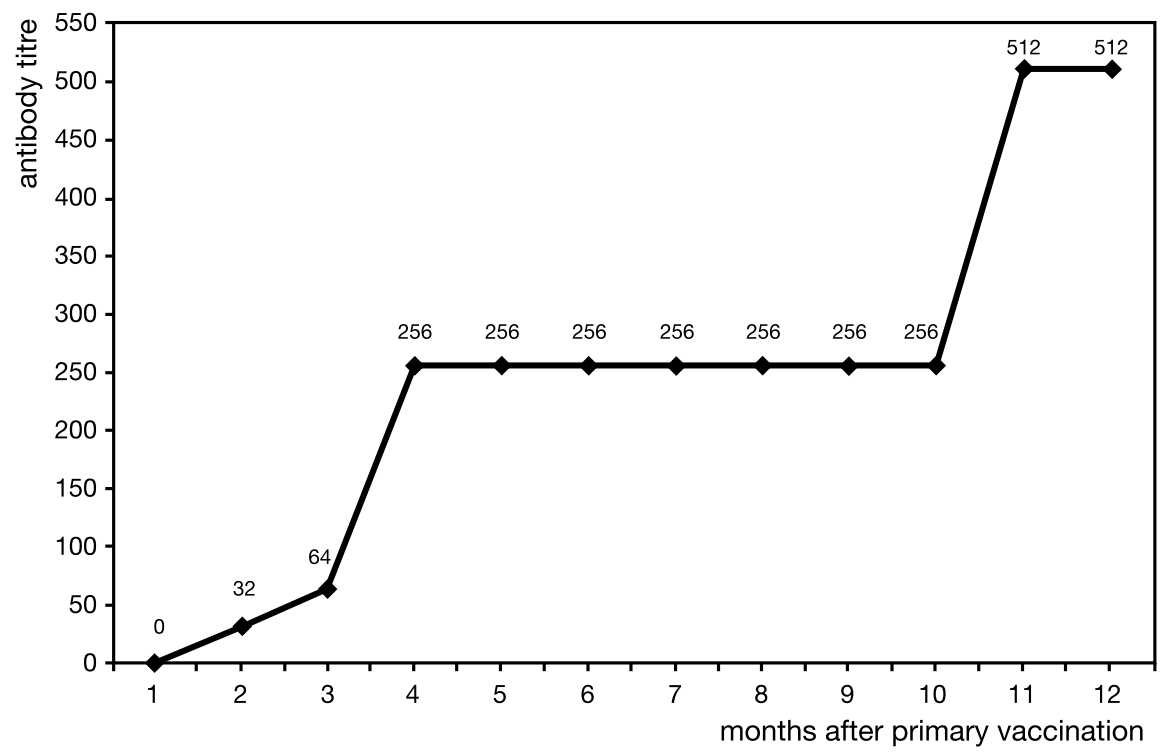

Fig 1. Development of anti-CDV antibody titre in ferret F1.

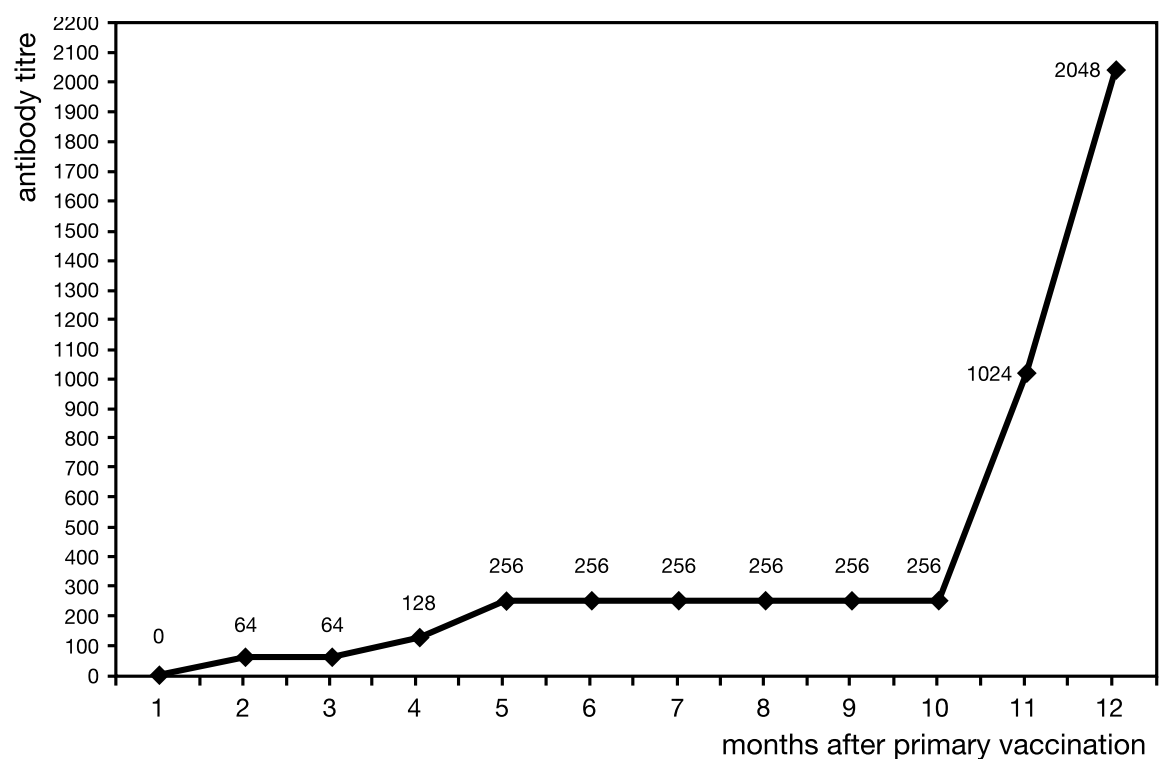

Fig 2. Development of anti-CDV antibody titre in ferret F3.

Svoboda 1998; Schoemaker 2002; Quesenberry and Orcutt 2004). The anti-CDV vaccines for ferrets registered in the US are Fervac-D (United Vaccines, Inc., Madison, WI) and PureVax (Merial, Athens, GA). Fervac-D is a modified live vaccine prepared on chicken embryos. PureVax is a recombinant vaccine prepared using a canarypox 
vector. Since the vaccine contains significantly reduced spectrum of CDV antigens and no adjuvants, it could be extremely suitable and safe. Another option is vaccine Galaxy D (Schering-Plough Animal Health Co., Omaha, NE). It is likely to be safe, but has not been verified satisfactorily yet. A suitable vaccination pattern involves primary vaccination at eight weeks of age with subsequent double revaccination at 3-week intervals followed by annual revaccinations (Quesenberry and Orcutt 2004; Langlois 2005).

Some authors regard anti-CDV vaccination of ferrets with combined vaccines intended for dogs as unsuitable (Quesenberry and Orcutt 2004). Their arguments include the higher risk of undesirable post-vaccination effects as well as insufficient immunoprotection (Schoemaker 2002; Lewington 2003). Undesirable post-vaccination reactions do exist, but no detailed records of these reactions are available (Quesenberry and Orcutt 2004). Greenacre (2003) reports an incidence of undesirable reactions in 143 ferrets after antiCDV vaccination over 5\%. On the other hand, Moore et al. (2005) report an incidence of undesirable reactions in a larger population $(3,587$ ferrets) to be under $1 \%$. Vaccination in ferrets is associated with nausea, vomiting, diarrhoea, erythema and fever. Ferrets should therefore be monitored for at least 30 minutes after vaccination (Langlois 2005). Should an undesirable post-vaccination response occur, administration of an antihistaminic (diphenhydramin chloride) is recommended. If a critical status occurs, epinephrine or dexamethasone should be administered and all standard critical-case emergency care measures should be applied (Rosenthal 2004). Some veterinary practitioners administer diphenhydramine preventively to ferrets with a previous complication episode 15 minutes before vaccination (Quesenberry and Orcutt 2004; Lewington 2003). Another recommendation is to administer only a part of the total volume $(1 / 2-1 / 6$ of the original dose for dogs) to ferrets (Lewington 2003). No negative post-vaccination reactions were observed in the course of this study in association with Biocan vaccines and the vaccine seems to be safe for ferrets.

Studies focused on the efficacy of anti-CDV protection of ferrets vaccinated with combined vaccines for dogs have still been scarce. In a similar study, ferrets vaccinated with a polyvalent vaccine for dogs were observed to produce antibodies (titres over 1: 128 ) as early as on post-vaccination day 30 , i.e. two weeks after revaccination (Hoover et al. 1989). On post-immunization day 243 antibody titres reached 16 - 64 (Hoover et al. 1989). Results testifying to the favourable effect of vaccination of ferrets with vaccines for dogs have recently been published, including cases when the original dose was reduced significantly (Roach 2004). Conversely, our results suggest that not even administration of a combined vaccine for dogs at the original dosage is bound to stimulate production of virusneutralisation antibodies in ferrets. While the vaccination led to no antibody production in three ferrets, antibody titre was found in the remaining two animals repeatedly from the second and third month after second revaccination on, even rising towards the end of the experiment. The rise in antibody titre we observed in the two ferrets at month 10 could be a consequence of the repeated contact of the animals with CDV. All animals were kept at constant conditions in the same room where contact with other CDV-sensitive animals was prevented. Had the animals been in contact with CDV, the three females would probably be infected, too, even though no virus-neutralisation antibody production was observed in them at that time. The reasons for the abrupt increase in antibody titre in the two ferrets remain unexplained. Regarding the results obtained in this study we do not consider that commonly recommended vaccination with a live attenuated anti-CDV vaccine is an effective method of antibodies induction against distemper in young ferrets. To be able to provide a clear answer to the question whether the type of vaccine tested by us can protect ferrets from the canine distemper virus effectively, the animals tested would have to be infected with a virulent CDV strain within an experimental setting. This test will be the subject of another study on a larger population of animals. 


\section{Sledování titru protilátek proti psince u fretek očkovaných živou modifikovanou vakcínou}

U skupiny pěti fretek vakcinovaných proti psince byl hodnocen nástup tvorby anti-CDV protilátek a po dobu jednoho roku byla sledována jejich sérová hladina.

$\mathrm{K}$ imunizaci byla použita živá atenuovaná vakcína. Vakcinace byla provedena podle schématu: primovakcinace ve věku 6 týdnů, první revakcinace za 30 dní po primovakcinaci a za dalších 30 dní druhá revakcinace. Krev byla odebrána před primovakcinací (odběr 0) a následně v třicetidenních intervalech (odběry 1 - 12). Celý cyklus vyšetření probíhal od primovakcinace ve věku 6 týdnů po dobu jednoho roku (do věku 1 roku a 6 týdnů). Vzorky sér byly vyšetřovány na př́itomnost virus neutralizačních protilátek proti CDV s využitím virus neutralizačního testu a CDV kmene Onderstepoort. Před primovakcinací byly u všech fretek zjištěny nulové titry virus neutralizačních protilátek. Dvě fretky zareagovaly po 1. revakcinaci tvorbou virus neutralizačních protilátek. Mezi 4. a 11. měsícem od primovakcinace byla udržována rovnoměrná hladina protilátek (titr 256) a v 11. a 12. měsíci došlo u obou zviŕat k náhlému vzestupu titrů protilátek (titr 512 a titr 1024 - 2048). Důvod náhlého vzestupu titrů protilátek u obou fretek zůstává nejasný. U tří zviŕat nebyla zjištěna ani po 3. revakcinaci a několikanásobně provedeném vyšetření sérokonverze proti viru psinky a nulové hodnoty titrů přetrvávaly po celou dobu studie. Na základě dosažených výsledků nepovažujeme obecně používaný systém očkování živou atenuovanou vakcínou za účinný způsob indukce př́itomnosti protilátek proti psince u mlád'at fretek.

\section{Acknowledgement}

This study was partially funded by the grant No. FRVŠ 230013 of the Ministry of Education, Youth and Sports of the Czech Republic.

\section{References}

ANTINOFF N 2004: Musculoskeletal and neurologic diseases. In: QUESENBERRY KE, CARPENTER JW (Eds): Ferrets, Rabbits and Rodents. Clinical Medicine and Surgery. $2^{\text {nd }}$ ed., WB Saunders, St. Louis, pp. $115-120$

APPEL MJ, HARRIS WV 1988: Antibody titres in domestic ferret ills and their kits to canine distemper virus vaccine. J Am Vet Med Assoc 193: 332-333

FOX JG 1998: Biology and Diseases of the Ferret. $2^{\text {nd }}$ ed., Williams and Wilkins, Baltimore, 568 p.

BROWN SA 1996: Basic Anatomy, Physiology, and Husbandry. In: HILLYER EV, QUESENBERRY KE (Eds): Ferrets, rabbits and rodents - Clinical medicine and surgery. W.B. Saunders Company, pp. 3-13

GREENACRE CB 2003: Incidence of adverse events in ferrets vaccinated with distemper or rabies vaccine: 143 cases (1995-2001). J Am Vet Med Assoc 223: 663-665

HAIG DA 1948: Preliminary note on the cultivation of green's distemperoid virus in fertile hen eggs. Onderstepoort J Vet Sci Anim Ind 23: 149-155

HOOVER JP, BALDWIN SA, RUPPRECHT CE 1989: Serologic response of domestic ferrets (Mustela putorius furo) to canine distemper and rabies virus vaccines. J Am Vet Med Assoc 194: 234-238

KELLEHER SA 2001: Skin diseases of ferrets. Vet Clin North Am Exot Anim Pract 4: 565-572

KENNEDY M 2005: Methodology in Diagnostic Virology. Vet Clin North Am Exot Anim Pract 8: 7-26

LANGLOIS I 2005: Viral Diseases of Ferrets. Vet Clin North Am Exot Anim Pract 8: 139-160

LEWINGTON JH 2003: Ferret, Husbandry, Medicine and Surgery. Butterworth Heinemann, Edinburgh, 289 p.

MCDONALD RA, LARIVIERE S 2001: Diseases and pathogens of Mustela spp., with special reference to the biological control of introduced stoat Mustela erminea populations in New Zealand. J Royal Soc NZ 31: 721-744

MOORE GE, GLICKMAN NW, WARD MP, ENGLER KS, LEWIS HB, GLICKMAN LT 2005: Incidence of and risk factors for adverse events associated with distemper and rabies vaccine administration in ferrets. J Am Vet Med Assoc 226: 909-912

NEWCOMER CE 1998: Exotic and Laboratory Animals. In: AIELLO SE (Ed.) The Merck Veterinary Manual. $8^{\text {th }}$ ed. Merck Whitehouse Station, pp. 1265-1431

QUESENBERRY KE 1997: Basic Approach to Veterinary Care. In: HILLYER EV, QUESENBERRY KE (Eds.) Ferrets, Rabbits, and Rodents. Clinical Medicine and Surgery. WB Saunders, Philadelphia, pp. 14-24

QUESENBERRY KE, ORCUTT C 2004: Basic Approach to Veterinary Care. In: QUESENBERRY KE, CARPENTER JW (Eds): Ferrets, Rabbits and Rodents. Clinical Medicine and Surgery. $2^{\text {nd }}$ ed., WB Saunders, St. Louis, pp. 13-24 
ROACH C 2004: Ferret vaccination - one tenth will do! Advances in Exotic, Zoo and Wild Animal Medicine, Zool Soc. London, $113 \mathrm{p}$.

ROSENTHAL KL 2004: Respiratory diseases. In: QUESENBERRY KE, CARPENTER JW (Eds): Ferrets, Rabbits and Rodents. Clinical Medicine and Surgery. $2^{\text {nd }}$ ed., WB Saunders, St. Louis, pp. $72-78$

RZEZUTKA A, MIZAK B 2002: Application of N-PCR for diagnosis of distemper in dogs and fur animals. Vet Microbiol 88: 95-103

SCHOEMAKER NJ 2002: Ferrets. In: MEREDITH A, REDROBE S (Eds): BSAVA Manual of Exotic Pets, $4^{\text {nd }}$ ed., BSAVA, Quedgeley, pp. 93-101

SVOBODA J 1998: Problematika chovu a chorob fretek (Keeping and diseases of ferrets). M. Lišková, Č. Těšín, 57 p.

STEPHENSEN CB, WELTER J, THAKER SR, TAYLOR J, TARTAGLIA J, PAOLETTI E 1997: Canine distemper virus (CDV) infection of ferrets as a model for testing Morbillivirus vaccine strategies: NYVAC-and ALVAC-based CDV recombinants protect against symptomatic infection. J Virol 2: 1506-1513

WIMSATT J, JAY MT, INNES KE, JESSEN M, COLLINS JK 2001: Serologic evaluation, efficacy and safety of a commercial modified-live canine distemper vaccine in domestic ferrets. Am J Vet Res 62: 736-740 